\title{
SHARI'AH-COMPLIANT E-COMMERCE MODELS AND CONSUMER TRUST
}

\author{
Muhammad Kholifatul I. Ardiansyarh, Yunizar \& Budi Harsanto
}

\begin{abstract}
Shariah-Compliant E-Commerce Models and Consumer Trust. This study is aimed at finding out the real picture of Shariah-compliant E-commerce model and consumer trust in e-commerce today, analyzing its drawbacks, and finding out how they influence each other. Shariab-compliant E-commerce model is a model that describes how e-commerce should run in accordance with the provisions of the Shariah. Broadly speaking, e-commerce in the perspective of Shariah must comply with some rules, namely: 1. the form of the offer and transaction agreement; 2. the transacting parties (buyers and sellers); 3. Objects and prices in the transaction; 4. Free from major prohibitions in transactions. The sample in this study is Indonesian citizen who are consumers of e-commerce. This research uses descriptive and statistical methods with multiple linear regression model. This model is considered relevant and good to be studied in order to enlighten how e-commerce is currently in the perspective of Islam.
\end{abstract}

Keywords: shariah-compliant; e-commerce; consumer trust; descriptive; linier regression

\begin{abstract}
Abstrak. Model Kepatuhan Syariab Pada E-Commerce dan Kepercayaan Konsumen. Penelitian ini bertujuan untuk memberikan gambaran utuh mengenai model kepatuhan syariah pada e-commerce dan kepercayaan konsumen atas e-commerce, kemudian menganalisisnya, dan mencari hubungan yang saling mempengaruhi di antara mereka. Model kepatuhan syariah pada e-commerce adalah suatu model yang menjelaskan bagaimana seharunya e-commerce beroperasi pada koridor yang sesuai dengan prinsip syariah. Dalam perspektif syariah suatu e-commerce harus mematuhi beberapa aturan, yaitu: 1. Perjanjian transaksi atau akad yang dipergunakan; 2. Transaksi antar penjual dan pembeli; 3. Objek dan harga transaksi; 4. Bebas dari berbagai transaksi yang dilarang dalam Islam. Sampel pada kajian ini ialah warga negara Indonesia yang merupakan konsumen dari e-commerce. Penelitian ini menggunakan analisis deskriptif dan model regresi linier berganda. Model ini relevan dan merupakan suatu kajian yang baik untuk memberikan penekanan bagaiaman seharusnya suatu e-commerce beroperasi dalam perspektif ekonomi Islam.
\end{abstract}

Kata kuci: kepatuhan syariah; e-commerce; kepercayaan konsumen; deskriptif; regresi linier 


\section{Introduction}

The development of technology has given people a new way to conduct commerce, such as: by using the Internet or usually called e-commerce. Based on research of Online Shopping Outlook 2015 issued by BMI research, the potential of the online market is so large. Internet users who conduct online transaction are estimated $24 \%$ of all Internet users. BMI Head of Research said, "Online shopping market in Indonesia will grow to $57 \%$ in 2015 , or approximately increase twice as last year. If it is seen from the turnover, BMI research also mentions that the value of spending in 2014 reached Rp. 21 trillion, with the average expenditure of Rp.825.000 per person. Assuming the same expenditure, it is predicted that in 2015 the value shall increase to Rp. 50 trillion. It is a positive condition for business growth of online shopping market in Indonesia". Practicality of use of Internet to conduct transaction provides a big enough impact to humans.

There are some benefit from online transactions (Al Arif, 2013): first, the operating hours that can operate for 24 hours. Second, the ease and speed in seeking products. Third, the ease of comparing prices on products. Fourth, easily done by anyone. Fifth, The cheaper investment. Besides the benefit, there are also arise some problems in online transactions, such as: first, the quality of products. Second, potential deceptive by the seller. Third, potential deceptive by the buyer (Al Arif, 2013).

In the process however, there are many shortcomings and obstacles in conducting transactions over the Internet. Because online environment is virtual and not a face-to-face interaction with each other, it can be said that the buyer has a weaker position than the seller in the transaction, resulting in a low level of trust for the buyer. Beatty et al. (2011) in Muhammad and Muhammad (2013) state that the success of e-commerce depends on trust, every vendor who fails to give consumers trust will not survive. Trust is said to be one of the factors that is so critical in online transactions (Luo, 2002). In the end, trust has become a critical issue for a better e-commerce transaction. Widyarini and Putro (2008) reveal that the concept of trust in e-commerce focuses on trust in the implementation of online transactions and trust in the operational mechanism of transactions. Muhammad and Muhammad (2013) reveal that the Islamic view regarding trust model in e-commerce is not much different from the regular one. But there are additional points which are in accordance with Islamic principles. This description has been adapted to the rules of Islamic law, namely Shariah-compliant E-commerce Model. This model is viewed more comprehensive because it includes religious values. 


\section{Literature Review}

According to Wigand (1997) in Whiteley David (2000), e-commerce is a transparent application of information and communication technology from the origin point to the end point along the entire value chain of business processes. This is done electronically and designed to allow the execution of business objectives. According to Efraim Turban (2002), e-commerce is the emerging concept describing the process of purchase, sale, or product exchange, services and information via computer networks, including the Internet. Trust is the key in e-commerce. E-commerce between two or more parties will occur if there is mutual trust. Trust is not automatically recognized by the other parties/business partners, but it must be built from the beginning and be proven. Trust has been considered as catalyst in various transactions between sellers and buyers so that customer satisfaction can be realized as expected (Yousafzai et al., 2003).

Mayer et al (1995) in Rofiq (2007) reveals that in online transaction, there are at least three seller characteristics that more or less can influence consumer trust. These are ability, benevolence, and integrity. Ability refers to skills, seller competence for its products, speed of delivery, and quality customer service. Benevolence is the level of trust of a seller which includes the desire to do good things in addition to earn legitimate profit. Integrity refers to compliance to the agreement or condition that has been made with the buyer. Cheung and Lee (2000) reveal that consumer trust in online transactions can be influenced by two factors, namely vendor trust and external environment. Vendor trust depends on the integrity and competence of the vendor, and controlling security and privacy of consumers. External environmental factor refers to the need for support from third parties and legal framework for the realization of a fair online transaction.

Muhammad and Muhammad (2013) reveal that the Islamic view of trust model in of e-commerce is not much different from the conventional model. The model is added with some points which comply with Islamic principles. These include: Fisrt, The form of offer and the transaction agreement; Second, Parties (buyers and sellers); Third, Objects and prices in transaction; Fourth,. Free from major prohibitions in the transaction, namely (i) the interest (riba), (ii) gambling (maysir), (iii) uncertainty (gharar), (iv) coercion (ikrah) and (v) prohibition (haram in nature). This description has been adapted to the rules of Islamic law, namely Shari'ah-compliant E-commerce Model.

Trust is a very important factor in establishing e-commerce transaction. Only the buyers who have trust in the seller will perform online transaction. This study examines how Shari'ah-compliant e-commerce model influences consumer trust. The framework of this research is as follows: 


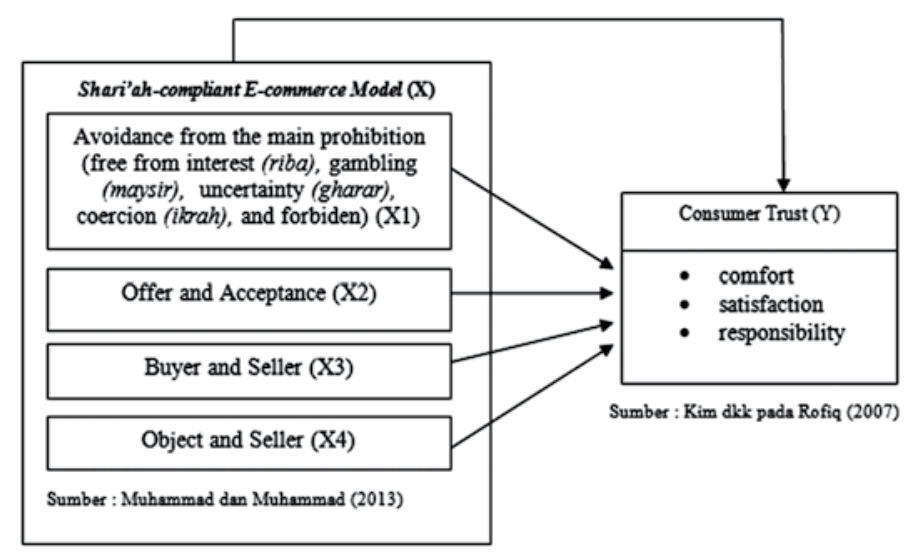

Figure 1 Framework of Study

\section{Hypotesis}

From the conceptual model, the research hypothesis is developed as follows:

H1: Shari'ah-Compliant E-commerce model has a positive influence on trust of e-commerce consumer

$\mathrm{H} 2$ : Free from major prohibitions (interest/riba, gambling/maysir, uncertainty/ gharar, coercion/ikrah, and haram) has a positive influence on trust of e-commerce consumer

$\mathrm{H} 3$ : Offers and agreements have a positive influence on trust of e-commerce consumer

H4: Buyers and Sellers have a positive influence on trust of e-commerce consumer $\mathrm{H} 5$ : Objects and prices have a positive influence on trust of e-commerce consumer

\section{Methods}

The population in this study is Indonesian citizen who become consumers of e-commerce. Due to the time limitation, we use sample taken from the population. The sampling technique used is purposive sampling. According to Sugiyono (2012), this technique is a way to determine sampling in which the sample is carefully chosen and must be relevant. The selection of the sample is based on the traits and particular characteristics desired by researchers. In this study, we chose respondents with following characteristics: (1) Have a minimum high school education level, with the assumption that the respondents understand the questionnaire well. (2) Respondents should understand the basic concepts of the use of e-commerce and 
have ever conducted online transaction (3) Respondents have done at least one online transaction over the last 3 months

Because the population is not known exactly and the unavailability of data of consumers, so the sample size determination is based on the opinion of Tabachnick and Fidell (2001). They say that the number of research sample using multiple regression model can be determined as follows:

$$
n \geq 50+8 m(1)
$$

$\mathrm{m}=$ number of independent variables used in the study

Based on this formula, the minimum sample number used in this study is determined as follows:

$$
\begin{aligned}
& n \geq 50+8 m \\
& n \geq 50+8(4) \\
& n \geq 50+32 \\
& n \geq 82
\end{aligned}
$$

Based on the calculation, a minimum sample size is obtained 82 . So, we decide that the number of respondent used in this study is 90 people.

\section{Result and Discussion}

There are two methods used in this study. The first method is descriptive method used to describe the situation and the second is verification method used to observe the relationship and influence of using statistical approach. Data in this study are collected through interviews and questionnaires.

\section{Validity Test, Reliability Test, and Multicolinearity Test}

Validity is a measure that indicates the level of validity of an instrument. An instrument is considered valid if it is able to measure what is desired (Simamora; 2004). Because the questionnaires use Likert scale generating ordinal data, the validity of the test is carried out by the approach of Spearman Rank correlation (Spearman Rho). Criterion or condition of an item to be valid if the correlation (r) of each item is positive and has a value of 0.3 or more (Sugiyono; 2012). Based on the result of data processing, it is obtained that every item has validity value above the critical limit $(>0.3)$.

Reliability is the level of questionnaire reliability. The questionnaire is reliable if it generates the same data when tested to the same group repeatedly. The assumption is that there is no psychological change in respondents (Simamora, 2004). Reliability test of research questionnaire in this study uses the 
formula Cronbach's alpha coefficient $(\alpha)$. Ghozali (2008) says that the standard of determining reliability of research instrument is that, it must have value of Cronbach Alpha more than 0.60 .

Multicolinierity test is done to see if there is a linear correlation or relationship between each of the independent variables. A good regression model does not show perfect correlation between independent variables. The independent variables are free from correlation if they have tolerance value of more than 0.19 or VIF $<10$. Based on statistics calculation, it is shown that there are no independent variables which have tolerance value of less than 0.10 . Besides, Variance Inflation Factor (VIF) also shows that none of the independent variables which has VIF value of more than 10 . So it can be stated that there are no multicollinearity between the independent variables in the regression model in this study.

Based on the recapitulation result on respondents, it is indicated that e-commerce is in accordance with sharia-compliant e-commerce model. It can be said that overall respondents feel that when they conduct e-commerce transaction, it conforms with Shari'ah-compliant e-commerce model. However, respondents are still unsure whether e-commerce will be free from major prohibitions (usury, maysir, gharar, and ikhrah). It is known that respondents show low level of e-commerce transaction because of major prohibitions, especially gharar/uncertainty. The barriers are conformity of the goods, price, delivery time, etc. Other variables in the study such as the form of offers and agreements, buyers and sellers, objects and prices are good in overall. These variables are in accordance with Shariah model.

In this research, there are five variables which are four independent variables and one dependent variable. Independent variables are the variable free from major prohibitions (usury, maysir, gharar, and ikhrah), offers and agreements, buyers and sellers, and objects and prices. While the dependent variable is consumer trust. Therefore, multiple linear regression analysis is used to examine the influence of two or more independent variables on dependent variable. Based on the result of the statistical calculation, the regression equation is formed as follows:

$y=-3,711-0,305 x_{1}+0,615 x_{2}+0,334 x_{3}+0,997 x_{4}$

Where:

$\mathrm{Y}=$ Consumer Trust

$\mathrm{X}_{1}=$ Free from major prohibitions

$\mathrm{X}_{2}=$ Offers and Agreements

$\mathrm{X}_{3}=$ Buyers and Sellers

$\mathrm{X}_{4}=$ Objects and Prices 
Seeing the condition of e-commerce today, we can see the low level of trust among respondents due to the major prohibitions. These prohibitions give negative impact on consumer trust.

Table 1 Coefficient of Determination

\begin{tabular}{ccccc}
\hline Model & R & R Square & Adjusted R Square & Std. Error of the Estimate \\
\hline 1 &, $564^{\mathrm{a}}$ &, 318 &, 289 & 5,09779 \\
\hline
\end{tabular}

According to Table 1, it is known that the value of R-square is 0,318 or $31.8 \%$. This number indicates that the variables free from major prohibitions (usury, maysir, gharar, and $i k h r a h)$, offers and agreements, buyers and sellers, and objects and prices influence consumer trust of $31.8 \%$, while the rest of $68.2 \%$ is influenced by other factors outside regression model in this study. From the table, it is also known the relationship strength between the independent variables and the dependent variable of 0.564 . This value is then categorized based on the Table 2 . Based on the Table 2, the correlation coefficient of 0.564 indicates that the relationship between independent and dependent variable is categorized moderate.

Table 2 Interval Coefficient Level Relation

\begin{tabular}{cc}
\hline Interval Coefficient & Level Relation \\
\hline $0,00-0,199$ & Very Low \\
$0,20-0,399$ & Low \\
$0,40-0,599$ & Medium \\
$0,60-0,799$ & Strong \\
$0,80-1,000$ & Very Strong \\
\hline
\end{tabular}

Source: Sugiyono (2012)

In this research, the F test is conducted to answer the first hypothesis. This is to find out whether independent variables positively, significantly and simultaneously influence dependent variable. The hypotheses of this test are:

Ho1: Shariah-Compliant E-commerce Model does not positively influence consumer trust in e-commerce

Ha1: Shari'ah-Compliant E-commerce Model positively influences consumer trust in e-commerce 
The decision rule or testing criteria is specified as follows $(\alpha=0,05)$ :

If F-count $>$ F-table or significance $<\alpha$, this means independent variables simultaneously influence dependent variable.

If F-count $<$ F-table or significance $>\alpha$, this means independent variables simultaneously do not influence dependent variable.

Table 3 Simultaneous Significance Test Results (Test F) ANOVA ${ }^{a}$

\begin{tabular}{cccccc}
\hline Model & Sum of Squares & Df & Mean Square & F & Sig. \\
\hline Regression & 1151,945 & 4 & 287,987 & 11,082 &, $000^{\mathrm{b}}$ \\
Residual & 2468,805 & 95 & 25,987 & & \\
Total & 3620,750 & 99 & & & \\
\hline
\end{tabular}

Based on the research result in Table 3, it can be seen that the significance values of independent variables (Shari'ah-Compliant E-commerce model) consisting of variables; free from the major prohibition (usury, maysir, gharar, and $i k h r a h)$, offers and agreements, buyers and sellers, objects and the prices are $0.000 \mathrm{a}(<\alpha)$. This means there is positive and significant independent variables (Shari'ah-Compliant E-commerce model) consisting of variables mentioned earlier on the dependent variable. In other words, it can be said that in $95 \%$ confidence level, Shari'ah-compliant e-commerce influences consumer trust. In this study, t-test is carried out to examine the significance between independent variables and dependent variable individually (partially). The hypotheses of this test are as follows:

Ho2: Free from major prohibitions (free from interest (riba), gambling (maysir), uncertainty (gharar), coercion (ikrah), and haram) do not have a positive influence on consumer trust in e-commerce

$\mathrm{Ha} 2$ : Free from major prohibitions (free from interest (riba), gambling (maysir), uncertainty (gharar), coercion (ikrah), and prohibition) have a positive influence on consumer trust in e-commerce

Ho3: Offers and agreements do not have a positive influence on consumer trust in e-commerce

Ha3: Offers and agreements have a positive influence on consumer trust in e-commerce

Ho4: Buyers and Sellers do not have a positive influence on consumer trust in e-commerce

Ha4: Buyers and Sellers have a positive influence on consumer trust in e-commerce 
Ho5: Objects and prices do not have positive influence on consumer trust in e-commerce

Ha5: Objects and prices have a positive influence on consumer trust in e-commerce The decision rules or criteria are as follows $(\alpha=0.05)$ :

If the $\mathrm{t}$-count $>\mathrm{t}$-table or significance $<\alpha$, this means independent variables partially influence dependent variable.

If $\mathrm{t}$-count $<\mathrm{t}$-table or significance $>\alpha$, this means independent variables partially do not influence dependent variable.

Table 4 Significance Partial Test Results ( $\mathrm{t}$ test)

\begin{tabular}{ccc}
\hline Model & $\mathrm{t}$ & Sig \\
\hline$($ Constant $)$ & -.938 &, 350 \\
$\mathrm{X}_{1}$ &,- 770 &, 443 \\
$\mathrm{X}_{2}$ & 2,017 &, 047 \\
$\mathrm{X}_{3}$ &, 956 &, 341 \\
$\mathrm{X}_{4}$ & 3,867 &, 000 \\
\hline
\end{tabular}

Based on Table 4, it can be concluded that: First, Ho2 is not rejected. It means that the major prohibitions do not have a positive influence on consumer trust in e-commerce. Second, Ho3 is rejected. It means that offers and agreements have a positive influence on consumer trust in e-commerce. Third, Ho4 is not rejected. It means that either the buyers and sellers do not have a positive influence on consumer trust in e-commerce. Fourth, Ho5 is rejected. It means that objects and prices have a positive influence on consumer trust in e-commerce.

The results of the assessment indicate that variable X1 (free from the major prohibitions) has a negative influence on consumer trust, but this is not significant. Variable X3 is in accordance with Shari'ah models but the influence is not significant. The main factors that positively influence consumer trust and significant are offers and agreements (X2) and objects and prices (X4).

According to Al Arif (2013) there are several things that can be done to increase consumer trust in online transaction. First, sellers must display the full specification of the products. Second, must be added the additional contract such as option (khiyar). Third, using a secure payment media. 


\section{Conclusions}

The purpose of this study is to describe consumers' response to the Shari'ahcompliant e-commerce model and their trust when doing e-commerce or online purchase and also to examine the influence of Shari'ah-compliant e-commerce model on consumer trust. After performing data collection, data processing and hypothesis testing, we draw the following conclusions: Respondents feel e-commerce conforms to Shariah-compliant e-commerce model. Nevertheless, respondents still have doubts that e-commerce is free from riba, maysir, gharar, and ikhrah. Respondents are doubtful that e-commerce is free from major prohibitions (usury, maysir, gharar, and $i k h r a h)$. The consumers are worried about the fitness of the real products with the images displayed by sellers on websites. They are also worried that the goods' quality does not correspond to the actual description. Besides, there are many online sellers who are deceptive, meaning the goods are not delivered even though payment has been made.

Respondents feel that offering and agreement processes are in accordance with shari'ah-compliant e-commerce model. These include connectivity between sellers and buyers, clarity of contract contents, and suitability of transaction result. However, partially, the respondents are doubtful about the suitability of the final result of the transaction. Respondents are sometimes cheated by sellers. This can be in the form of undelivered goods or the goods do not match the description. Respondents feel that transacting parties (buyers and sellers) are in accordance with the shariah-compliant e-commerce model. This includes buyers and sellers; are already qualified in general, have the goods and money for transaction, and able to perform the transaction fairly. However, there are some respondents who question the responsibility of sellers when the goods are not suitable with the agreement. Sellers tend to stay away or do not want to resolve the issue properly.

Respondents feel Objects and Prices are in accordance with the shari'ahcompliant e-commerce model. This means goods; have legal aspect, have value, can change in terms of ownership, and have fitness with the agreement made earlier. Respondents quite believe that sellers will provide comfort, safety, and responsibility when conducting e-commerce transactions. Shari'ah-compliant e-commerce model consisting of variables free from major prohibitions (usury, maysir, gharar, and ikhrah), offers and agreements, buyers and sellers, and objects and prices simultaneously, positively, and significantly influence consumer trust. It can be said that the more e-commerce is in accordance with the shari'ah-compliant e-commerce model, the stronger consumer's trust is. Through the calculation of the partial influence of the variables, the variable free from major prohibitions (usury, maysir, gharar, and ikhrah) has negative and insignificant influence on 
consumer trust. Thus, it can be said that this variable does not influence consumer trust. The variable offers and agreements positively and significantly influence consumer trust. The more appropriate are the offers and agreements with shari ahcompliant e-commerce model, the higher consumer trust is. The variable buyers and sellers positively influence consumer trust but not significant. Thus, it can be concluded that buyers and sellers do not really influence consumer trust And lastly, the variable objects and prices positively and significantly influence consumer trust. Therefore, the more objects and prices are in accordance with the shari'ah-compliant e-commerce model, the higher consumer trust is. The variable consumer trust can be explained $31.8 \%$ by the variable Shariah-compliant e-commerce model, and the remaining $68.2 \%$ is influenced or explained by other factors.

\section{References}

Al Arif, M.N.R. (2013). Penjualan On-line Berbasis Media Sosial Dalam Perspektif Ekonomi Islam. Ijtihad: Jurnal Wacana Hukum Islam dan Kemanusiaan. Vol. 13 (1): 33-48.

Cheung, C. \& M.K.O. Lee. (2000). Trust in Internet Shopping: a Proposed Model and Measurement Instruments. In Proceedings of American Conference of Information Systems, Long Beach, CA.

Ghozali, I. (2008). Statistik Non-Parametrik: Teori \& Aplikasi dengan Program SPSS. Semarang: Badan Penerbit Universitas Diponegoro.

Kim, D. J. et.al. (2007). A Trust-Based Consumer Decision Making Model in Electronic Commerce: The Role of Trust, Perceived Risk, and Their Antecedents. In Proceedings of Ninth Americas Conference on Information Systems,

Mayer, R.C. et.al. (1995). An integrative model of organizational trust. Academy of Management Review. Vol. 20 (3): 709-734.

Muhammad, M.R. \& M. Marjan. (2013). Building Trust in E-Commerce: A Proposed Shari'ah Compliant Model. Journal of Internet Banking and Commerce. Vol. 18, no.3: 251-260.

Simamora, B. (2004). Riset Pemasaran: Falsafah, Teori, dan Aplikasi. Jakarta: PT Gramedia Pustaka Utama.

Sugiyono. (2012). Metode Penelitian Kuantitatif dan Kualitatif (Mixed Method). Bandung: Alfabeta.

Whiteley, D. (2000). Electronic Commerce. Jakarta: PT Indeks Ekompok Gramedia. 
Widyarini, L.A. \& A.Y.W.T. Putro. (2008) Analisis Hubungan Faktor-faktor Technolog Acceptance, Trust dan Risk pada Niat Nasabah Bank untuk Menggunakan Internet Banking. In The 2nd National Conference UKWMS. Surabaya 6 September.

Yousafzai, S. Y. et.al., (2003). A Proposed Model of eTrust for Electronic Banking. Technovation. Vol. 23: 847-860. 